\title{
FESTA E GUERRA NA ESPLANADA: SONS DA POLÍTICA NUM ACAMPAMENTO TERRA LIVRE
}

\author{
Party and war at the Esplanade: \\ sounds of politics at a Free Land Camp \\ Fiesta y guerra en la Explanada: \\ sonidos de la política en un Campamento Tierra Libre \\ Mario de Azevedo Brunoro ${ }^{1}$ \\ Rafael Monteiro Tannus ${ }^{2}$
}

\section{Resumo:}

Esse artigo busca construir uma leitura sobre o principal evento político dos povos indígenas no Brasil, o Acampamento Terra Livre (ATL), a partir das propostas teóricas desenvolvidas por Beatriz Perrone-Moisés (2015) de assumir o par festa-guerra enquanto possível chave de compreensão da política ameríndia. Num primeiro momento, pretendemos apresentar ao leitor qual o conjunto de referências mobilizadas ao falarmos da política em outros termos, isto é, o que significa dizer que festejar é fazer política? Passamos, em seguida, a uma apresentação do ATL e dos principais elementos etnográficos que fundamentam a análise. Finalmente, levamos o leitor para dentro do Acampamento, tentando explorar o caráter imbricado dessa política com a música e os cantos dos diversos povos - amazônicos, mas não só - que se reuniram no evento, bem como do ATL como lugar privilegiado para observar a indigenização da política. Apesar de ser uma articulação aos moldes dos brancos, não deixa de ser afetado pelos modos ameríndios de fazer política, seja na festa ou na guerra - e sempre com música.

Palavras-chave: Política indígena; estética e política; artes verbais

\begin{abstract}
:
\footnotetext{
${ }^{1}$ Bacharel em Ciências Sociais pela Universidade de São Paulo.

${ }^{2}$ Bacharel em Ciências Sociais pela Universidade de São Paulo.
}

This article aims to analyze Brazil's main indigenous political gathering, the Free Land Camp (ATL), as seen from the theoretical framework developed by Beatriz Perrone-Moisés (2015) which proposes the pair party-war as a possible key concept for understanding indigenous politics. At first, we intend to present the reader with the set of references mobilized when we talk about politics in other terms: what does it mean to say that to celebrate is to do politics? We then move on to a presentation of the ATL and the main ethnographic elements that underlie the analysis. Finally, we take the reader inside the Camp, trying to explore the intertwinement between this expression of politics and the music and chants of the many peoples - Amazonians, but not only - who were brought together for this event, as well as the ATL as a privileged event to observe 
the indigenization of politics. Despite being a movement in a non-indigenous sense, it is still affected by Amerindian ways of doing politics, whether at party or at war - and always with music.

Keywords: Indigenous politics; aesthetic and politics; verbal arts

\section{Resumen}

Este artículo busca construir una lectura sobre el principal evento político de los pueblos indígenas en Brasil, el Acampamento Terra Livre (ATL), a partir de las propuestas teóricas desarrolladas por Beatriz Perrone-Moisés (2015) de asumir la pareja fiesta-guerra como una posible clave de comprensión de la política amerindia. En un primer momento, pretendemos presentar al lector el conjunto de referencias que movilizamos cuando hablamos de 'política en otros términos', es decir, ¿qué significa la idea de que hacer fiesta es hacer política? Luego pasamos a una presentación del ATL y los principales elementos etnográficos que subyacen al análisis. Finalmente, llevamos al lector al interior del campamento, tratando de explorar tanto el carácter entrelazado de esta política con la música y cantos de los diversos pueblos - amazónicos, pero no solo - que se reunieron en el evento, cuanto lo de ATL como lugar privilegiado para observar la indigenización de la política. A pesar de ser una articulación a los moldes de los blancos, todavía se ve afectada por las formas amerindias de hacer política, ya sea en la fiesta o en la guerra, y siempre con la música.

Palabras clave: Política indígena; estética y política; artes verbales

\section{A política em outros termos}

A antropologia e os antropólogos, de uma forma ou de outra, sempre estiveram às voltas com a "política dos índios". Mesmo que a antropologia política enquanto subárea da disciplina tenha tomado forma somente nas décadas de 1930 e 40 com as pesquisas africanistas do estrutural-funcionalismo britânico (GOLDMAN \& LIMA, 2003, p. 11), as figuras dos chefes e a problemática das instituições de poder nas sociedades tradicionais perpassam os escritos de etnógrafos muito antes disso. As tentativas de enxergar entre os povos da América, sobretudo - uma figura que concentre em si prerrogativas de dominação sobre os demais, entretanto, jamais conseguiram dar conta daquilo que esses povos efetivamente viviam e vivem. Os recortes de dimensões sociais feitos por nós - economia, parentesco, religião, política - não encontram respaldo nos discursos e práticas ameríndias. Estes, ao contrário, torcem e deslocam nossas proposições. E é exatamente isso, aliás, que a prática antropológica persegue.

Já no século XVIII, Canasatego, liderança da Nação Onondaga e orador da Confederação Iroquesa, apontava em discurso que "diferentes Nações têm diferentes concepções". E são essas diferentes concepções que os nossos recortes são incapazes de abarcar. Na procura por uma política à moda dos povos indígenas, a própria categoria "política" já configura um problema de saída, pois exclui elementos que não necessariamente estão ausentes em outras concepções possíveis do político. E é a questão colocada por uma política que aparece por vezes como da ordem do "religioso", do "ritual" ou do "parentesco", pela figura de um "chefe sem poder", que Beatriz Perrone-Moisés (2015) persegue em ensaio iluminador, em que pretende exatamente alargar os nossos conceitos à luz daquilo que podemos imaginar dos conceitos ameríndios, no caso, de política.

O problema da chefia ameríndia é também o principal tema abordado por Pierre Clastres, filósofo e antropólogo mais conhecido por cunhar o conceito de Sociedades contra o Estado. A questão central de 
seus escritos, que continua a orientar Perrone-Moisés, é, justamente, o paradoxo de uma chefia sem poder. Se, para ter acesso à chefia, é necessário possuir o dom da oratória, por que o discurso do chefe é tão pouco ouvido? Por que não lhe prestam atenção?

Esse paradoxo conduz Clastres a uma crítica ao modelo da reciprocidade de Lévi-Strauss. Ele identifica que os elementos definidores da chefia ameríndia possuem os mesmos signos que Lévi-Strauss aponta como da reciprocidade: bens, palavras e mulheres. O chefe deve ser generoso em relação a seus bens, sem o privilégio do acúmulo; deve ser um bom orador, e, além de proferir falas diárias, é ele que, por meio da palavra, "faz a paz", "é a instância moderadora do grupo" (CLASTRES, 2003, p. 48). Além disso, ao chefe é concedido o direito (em muitos casos, privilégio) à poliginia.

Contudo, na chefia, esses signos movimentam-se numa só direção, não são trocados. Não é o princípio da reciprocidade que a rege. A fala do chefe é dissociada da comunicação, pois ninguém a ouve. Sua generosidade obriga-o a distribuir seus bens, e o impede de demandar algo em troca. Seria a poliginia, então, a forma com que o grupo efetuaria a troca recíproca com o chefe? Para Clastres, tal déficit é insanável (2003, p. 59) e o chefe está em eterna dívida com o grupo. Sua posição, a função política, é alheia às normas da vida social. E, é nessa posição que Clastres encontra o que seria o coração da filosofia política das sociedades contra o Estado.

Não se trata de troca, mas de "doação sem contrapartida, aparentemente destinada a sancionar o estatuto social do detentor de um cargo instituído para não se exercer" (idem). A instância da chefia é, na verdade, representante da vontade do grupo, mas não do poder. O poder permanece no próprio corpo social, que o exerce de modo a encarregar à chefia o dever de deixar aparente sua vontade contra Estado:

Da boca do chefe saem, não as palavras que sancionariam a relação de comando-obediência, mas o discurso da própria sociedade sobre si mesma, discurso por meio do qual ela se autoproclama comunidade indivisa e vontade de perseverar nesse ser indiviso (CLASTRES. 2004, p. 104).

Trata-se de uma negação controlada por uma intencionalidade sociológica (Goldman e Lima, 2003, p. 18), que articula a disjunção entre poder e coerção. É negação da cultura, pois rompe com a reciprocidade, e é controlada porque perpassa o campo de intencionalidades, conscientes e inconscientes, contra o "germe de um poder centralizado e coercitivo, um 'Estado em devir"' (PERRONE-MOISÉS, 2011, p. 862).

No campo da linguagem, enquanto as sociedades com Estado enxergam a palavra como direito do poder, as sociedades contra o Estado a imaginam como dever do poder ${ }^{3}$. Essa imposição à instância do poder impede que ela tome formas coercitivas, e que sua fala se torne uma de palavras de ordem. Conjuram a forma Estado. As palavras e ações dos chefes ameríndios são caracterizadas por elementos de outras ordens, que tendemos a isolar em categorias como musicalidade e poética, privando-as da política - e a política, delas. Clastres abre um caminho orientado a não operar com tais separações e a observar falas, cantos, danças como ações políticas, em movimento a uma Revolução Copernicana, com o intuito de se atentar ao que seria de fato uma filosofia política ameríndia.

Esse movimento, contudo, pode se direcionar em sentidos distintos: tanto "em prol de uma teoria geral da política" quanto em "buscar os termos ameríndios de conceber e praticar política" (PERRONE-MOISÉS, 2011, p. 857). Tal ponto é fundamental para entender a continuidade da antropologia clastreana proposta por Perrone-Moisés, pois, diferentemente de Clastres, que, ao perseguir o que seria uma filosofia

\footnotetext{
${ }^{3}$ Chefia Indígena - Pierre Clastres. H. Pougy, disponível em http://ea.fflch.usp.br/conceito/chefia-ind\%C3\%ADgena-pierre-clastres
} 
da chefia indígena, também formulou uma teoria geral da política (como enunciado a cima), Perrone-Moisés busca imaginar, nos possíveis do nosso pensamento, as próprias teorias políticas indígenas. Para isso, a antropóloga privilegia os termos que os ameríndios usam conscientemente para falar de relações políticas: "anfitrião-convidado (em clave de Festa); amigo-inimigo (em clave de Guerra)". Trata-se de um ajuste no vocabulário analítico-descritivo em direção às próprias traduções indígenas (no sentido de um "português dos índios"), e que desloca uma série de questões pertinentes à política ameríndia (2015, p. 6, 7, 38).

A vantagem é que tal deslocamento nos permite dar continuidade ao que Clastres $(1974,1980)$ havia observado sobre os chefes ameríndios, mas, em vez de encarar a chefia sem poder apenas como liderança política, estendê-la a todas as suas variações, assim como o fazem os ameríndios. Chefes, xamãs, "donos, sogros, chefes de guerra, líderes de caçadas, donos de aldeias etc. são variantes de uma relação entre quem dá existência (no sentido de originar e alimentar) a sujeitos que o fazem ser quem é. Puxador e seguidores" (PERRONE-MOISÉS, 2015, p. 7).

E eis que, à moda de uma aldeia timbira com seus caminhos radiais, ao perseguir os "termos da política ameríndia”, as mais diversas vias conduziram Perrone-Moisés à festa (também nas acepções ameríndias deste termo): "todos os caminhos de pesquisa trazem-me ao pátio, 'salão de festa"' (2015, p. 4). Buscar a política e encontrar a festa. Este o percurso que informa toda a sua reflexão, oriunda de uma observação com a qual Merekuku Apalay, um chefe Aparai, "presenteou-a", ao dizer que "dono de festa é como chefe" (idem).

\section{O Acampamento Terra Livre}

Pretendemos, neste breve ensaio, desenvolver as propostas teóricas de Perrone-Moisés numa leitura daquele que vem se configurando como o principal evento político dos povos indígenas no Brasil: o Acampamento Terra Livre (ATL). Encabeçado pela Articulação dos Povos Indígenas do Brasil (Apib) em conjunto com outras organizações indígenas pelo país afora, o ATL tem como objetivo "[r]eunir em grande assembleia lideranças dos povos e organizações indígenas de todas as regiões do Brasil para discutir e se posicionar sobre a violação dos direitos constitucionais e originários dos povos indígenas e das políticas anti-indigenas do Estado brasileiro"4. Chegando à sua 14a edição em 2017, o ATL reuniu em Brasília, entre os dias 24 e 28 de abril, cerca de 4.000 indígenas de quase 200 povos diferentes, vindos de todas as regiões do país e de toda a Amazônia brasileira. Havia sido, até então, a maior Mobilização Nacional Indígena da história recente ${ }^{5}$. Brasília só abrigara tantos indígenas juntos assim na época das mobilizações pela Constituinte. Uma verdadeira festa na Esplanada, cenário dos mais propícios, contudo - ainda mais para os povos indígenas, ainda mais em 2017 -, à guerra (a adversativa aí é necessária somente na nossa lógica relacional, que não vê complementaridade no par festa-guerra).

O evento é tratado mais comumente na mídia pelo viés de suas relações com o Estado e da conjuntura das políticas indigenistas (cada vez mais anti-indígenas), sem dúvida definidoras e definitivas para o que acontece ali e para as perspectivas de futuro dos índios. Privilegiaremos aqui, no entanto, uma leitura pelos vieses do que outros autores tomam como matrizes relacionais do pensamento e da socialidade ameríndios (entre os quais, por exemplo, o plano festa e guerra proposto por Perrone-Moisés ou o dualismo em perpétuo desequilíbrio formulado por Lévi-Strauss). Uma perspectiva, em suma, que tenta se aproximar de uma perspectiva indígena (ou àquilo que dela podemos imaginar, no sentido forte da palavra, em nosso diálogo com ela enquanto antropólogos e/ou indigenistas).

\footnotetext{
${ }^{4}$ Retirado da Convocatória para o 14ㅇAㄴ, disponível no blog da Apib: https://mobilizacaonacionalindigena.wordpress.com/2017/03/20/convocatoria-acampamento-terra-livre-2017/

${ }^{5}$ Ver https://mobilizacaonacionalindigena.wordpress.com/2017/04/28/o-maior-acampamento-terra-livre-da-historia/
} 
Com efeito, mostrou-se produtiva a análise dos acontecimentos que se desenrolaram naquela semana de abril pela grade do plano festa-guerra - plano que atravessa os nossos divisores tradicionais, permitindo-nos ver com mais clareza o que se passa. Se "é na operação conjunta (alternada e contraposta, como convém a um par ameríndio) dessas grandes matrizes relacionais que se situa a vida social, i.e., coletiva, dos povos nativos das Américas" (PERRONE-MOISÉS, 2015, p. 6), podemos então pensar uma reunião do porte do ATL nessa chave, "[d]a Festa como matriz e [d]a relação anfitrião-convidado como modelo" (idem, p. 38). Ainda que, neste caso, por se tratar de uma enorme festa na qual a interface com o Estado brasileiro desempenha papel constitutivo, sejam necessários ajustes em alguns pontos da análise. Desses deslocamentos, trataremos adiante.

Para além do desenvolvimento das sugestões teóricas de Perrone-Moisés, pretendemos traçar um esboço de análise de outro elemento que muito prendeu nossa atenção ao longo de todos os dias do evento: a centralidade que os cantos e a música desempenharam entre todos os povos e nos mais diversos espaços e ocasiões. Inspirados livremente pela proposta de Rafael Menezes Bastos do ritual como língua franca no Alto Xingu, propomos pensar a música como língua franca - juntamente com, mas não da mesma forma que o português - da ação política ameríndia. E é bom lembrar (ou antecipar), que, quando pensamos e nos referimos aqui à "música", a dança está implicada. Não se fazem independentemente, uma vez que não há música separada do corpo se consideramos que música “[é] o uso do corpo para produzir e acompanhar sons” (SEEGER, 2015, p. 16).

Contrastando a uma antropologia da música, Anthony Seeger propõe uma antropologia musical, que deveria considerar a "maneira como as performances musicais criam muitos dos aspectos da cultura e da vida social" (idem, p. 14). No caso aqui discutido, destacamos a maneira pela qual a política ou, para colocar de forma mais ampla, o político, está na música e se faz por ela. Para se tentar compreender uma política musical, então, exige-se uma antropologia musical no sentido colocado por Seeger. Uma antropologia política que releve ou que coloque em segundo plano o que os faz cantar - e o que fazem esses cantos - certamente quedará longe daquilo que parece constituir "política" entre os ameríndios.

Os cantos e a música apareceram-nos como uma espécie de sistema pivô da manifestação, intermediando a ação de pessoas que falavam diversas línguas, fazendo e desfazendo grupos nos atos que atravessaram a Esplanada, enfim, produzindo e (des)ordenando um certo estado de coisas, de forma a expressar uma qualidade agentiva. E isso tudo não nos rituais locais, em suas aldeias, mas na capital do país, aos pés da sede de todos os ministérios e dos três poderes federais. Uma eloquente metáfora (mas não só!) do caráter contra-o-Estado das paisagens sonoras ali desenhadas.

\section{Entre políticas, entre festas, entre outros}

O sol do planalto central já se fazia sentir na pele quando chegamos ao enorme gramado que sediaria o evento. No Eixo Monumental, sobre mais terra do que grama (a poeira impregnou por meses os computadores e equipamentos que carregamos), começava a tomar forma o $14^{\circ}$ Acampamento Terra Livre. Montado num extenso descampado ao lado do Teatro Nacional, próximo ao início da Esplanada dos Ministérios, vislumbrava-se do lado oposto a Catedral Metropolitana de Nossa Senhora Aparecida e, ao fundo, quase no horizonte, as torres do Congresso Nacional. As delegações chegaram ao longo de toda a segunda-feira, outras só desembarcaram no dia seguinte. Mas antes mesmo do almoço, miçangas de todos os cantos e cores já pisavam no chão do acampamento. Quanto a nós, fomos a Brasília enquanto estagiários do Programa Monitoramento de Áreas Protegidas do Instituto Socioambiental (ISA). E como parte da equipe de comunicação trabalhando no acampamento, circulamos em ritmo intenso, tentando dar conta dos estímulos que, de todo lado, pipocavam aos olhos de antropólogos em formação. 
O Acampamento centrava-se numa grande tenda principal, palco dos pronunciamentos e apresentações. No seu entorno, outras tendas menores destinadas às diversas funções da organização: uma tenda médica, uma para a imprensa e comunicação, uma outra que servia de cozinha. Logo em frente à tenda principal, montaram suas barracas - tão grandes quanto suas delegações - os povos do Rio Negro e os povos xinguanos, presentes em peso no evento. Outras áreas mais distantes já eram ocupadas logo de início, estabelecendo uma área periférica em relação a esse "pátio central". Ao fundo, instalava-se uma delegação Xavante, ao seu lado alguns Munduruku. Descendo em direção à Esplanada, uma enorme área guarani, em seguida, os Kaingang, e mais adiante ainda e espalhados, delegações de povos do Nordeste - Potiguara, Pankararu, Pataxó, Xukuru. A composição crescia e se diversificava a cada hora no primeiro dia.

No corredor entre a tenda principal e as grandes barracas, tomou forma um grande centro de trocas de mercadorias do acampamento, replicando em menor escala um tipo de mercado de Marrakech, tamanha a vitalidade de transações que ali se instalou. Por metros e metros no chão, exibiam-se colares e pulseiras de todos os tamanhos e padrões dos xinguanos; diante dos rionegrinos, instrumentos de madeira e adornos plumários dos mais variados; mais a frente, uma tenda exclusivamente para as peças kayapó - todos oferecendo, além disso, as possibilidades de pinturas corporais feitas na hora. Do outro lado, indígenas do Nordeste exibiam também artesanatos, colares de sementes, plantas medicinais e ervas diversas, bolsas, cestos. Outros, ainda (alguns deles ambulantes locais brancos), ofertavam opções mais heterodoxas aos nossos olhos (e nem por isso menos "tradicionais"), como óculos escuros - talvez um dos maiores sucessos de vendas -, acessórios para celulares e equipamentos eletrônicos diversos. $\mathrm{E}$ as transações eram sobretudo intensas entre os próprios indígenas - alguns Xavante adquiriam com efusividade pares de óculos de sol, enquanto uma mulher Pataxó pechinchava um colar kĩsêdjê. O comércio e as trocas não cessaram ao longo da semana.

A tenda central consistia num palco em que as lideranças discursavam e numa vasta plateia preenchida por cadeiras. Entre ambos, um espaço aberto, feito de "pista de dança". Do palco, ecoavam falas inflamadas de muitas lideranças e membros de organizações indígenas. Vários informes foram dados e discursos políticos (aqui, no sentido mais próximo ao que nós damos à palavra), proferidos. Essas sucessivas falas ao microfone, por um lado, assemelhavam-se às das assembleias de movimentos dos brancos. $\mathrm{O}$ tom, as exortações combativas, os termos e expressões recorrentes na militância, poderiam enganar ouvidos desatentos e os conduzir à impressão de estar numa reunião como tantas outras da política à nossa moda. O ATL, efetivamente, vai ao encontro de uma maneira organizativa própria dos brancos. É uma instância criada, de certa forma, para os brancos e em razão deles.

O próprio formato de organizações indígenas, com CNPJ, diretorias eleitas, contas bancárias, impôs-se aos povos indígenas a partir de suas necessidades de mediar relações com o Estado e o mercado. Esse movimento, intensificado sobretudo após a Constituição de 1988, expressa, "a rigor, [a] incorporação, por alguns povos indígenas, de mecanismos de representação política por delegação, para poder lidar com o mundo institucional, público e privado, da sociedade nacional e internacional" (RICARDO, 1996, p. 90), instâncias necessárias para tratar com atores com os quais precisam, cada vez mais, negociar suas demandas (territoriais, assistenciais, comerciais, ambientais). Esses instrumentos, contudo, também são armas dos brancos que os indígenas domesticam a seu favor. Tecnologias de guerra das quais se apropriam, colocando num mesmo grupo de transformação a borduna, o pó de yãkoana, o microscópio, o Direito e a língua portuguesa - já que "as guerras hoje são 'de palavras”' (cf. PERRONE MOISÉS, 2015, p. 69).

Nesse sentido, deslocando a impressão inerte de semelhança que as falas poderiam causar, uma aproximação do contexto também poderia ser feita à obrigação dos chefes ameríndios em doar palavras. Os que chegavam davam suas falas, saudações, conselhos, expectativas, críticas. Mesmo que, como nas aldeias, muitos não prestassem grande atenção ao conteúdo dessas falas. Havia uma plateia atenta nas cadeiras mais próximas, mas a 
vida e as interações ao redor prosseguiam pouco afetadas à semântica. A periferia seguia viva em seu dinamismo sob a fumaça dos cachimbos e o som de maracás. O que parecia importar era que houvesse alguém falando.

Essa relação entre o "pátio" e a "periferia" que subverte o nosso modo de olhar - mostrando que os holofotes não apontam necessariamente ao mais importante - foi notada de maneira muito similar por Laura Graham na Semana da Paz, encontro que reuniu povos indígenas, seringueiros e populações tradicionais em 1987, numa dinâmica política análoga à do ATL. A autora observa que "na Semana da Paz, reuniões que aconteciam separadas das sessões abertas ao público eram importantes fóruns em que participantes familiarizavam-se com as situações uns dos outros" (Graham, 2002, p. 195, tradução nossa). João Tapajós, liderança do baixo Tapajós, fez uma observação nesse mesmo sentido acerca do ATL: "Acho que o ATL faz com que a gente dialogue com outros povos e veja que a realidade da gente não é tão distante da outra. E aí a gente começa a unificar essas pautas”.

Na manhã do segundo dia de acampamento, a tenda principal foi destinada a apresentações das delegações presentes. Elas constituíram blocos organizados, em sua maioria, conforme a organização regional correspondente. A "pista" era tomada pela dança dos recém-chegados. "[O]s convidados", nota Perrone-Moisés "parecem ter sempre a obrigação de dançar; de todo modo, sempre têm de dar algo." (2015, p. 76 nota 58). Na medida em que se reuniam sob dada organização indígena, configuravam-se discrepâncias: a Coordenação das Organizações Indígenas da Amazônia Brasileira (Coiab) entrou com mais de uma centena de pessoas dançando e cantando, de forma a ocupar toda a área disponível da tenda, enquanto os representantes do Piauí juntavam esforços em meia dúzia de pessoas erguendo a faixa "No Piauí tem índio sim". Mas, assim como os indígenas do Piauí somavam em si uma única delegação, organizações como a Coiab e a Articulação dos Povos e Organizações Indígenas do Nordeste, Minas Gerais e Espírito Santo (Apoinme) congregavam e articulavam dezenas de delegações diferentes. Antes de se apresentarem, os blocos de convidados esperavam enfileirados fora da tenda, cantando, dançando e fumando. Adentravam-na e, após toda a apresentação, dispersavam-se pelo acampamento. Havia momentos em que as músicas eram tantas e de tantas pessoas ao mesmo tempo, que se instalava a impressão de um amálgama sonoro, no sentido de uma grande ressonância entre os cantos, que passavam a compor uma massa indiscernível de sons.

Chegamos a um primeiro ajuste teórico que o caso etnográfico nos exige. O modelo desenvolvido por Perrone-Moisés, bem como outras reflexões acerca da chefia ameríndia, trata de relações inter-aldeãs, geralmente locais ou regionais. Pensam a chefia em relação aos demais membros da comunidade e a comunidades próximas (aliadas e/ou potencialmente inimigas). Mesmo contextos como os do Alto Xingu ou do Alto Rio Negro, onde se estabelecem redes mais amplas e espalhadas, configuram, ainda assim, um certo sistema cultural, um fundo comum a todas as comunidades que dele participam, por mais diversas que sejam entre si.

No ATL, contudo, encontramo-nos num cenário em que é mais difícil vislumbrar um fundo compartilhado. As diferenças talvez saltem aos olhos mais facilmente que as semelhanças - que, por óbvio, estão lá. Os trabalhos das figuras anfitriãs, nesse caso, complicam-se ainda mais. Para "puxar" uma reunião, uma turma ou uma festa aqui, precisam congregar diferenças intensificadas. Além disso, a maioria presente é, de alguma forma, chefe. Grupos de lideranças e suas respectivas turmas, em sua maior parte desconhecidos entre si, relacionando-se. É como se estivéssemos num âmbito das relações internacionais indígenas, por assim dizer. Diferentes "nações", para usar uma terminologia antiga, articulando-se umas às outras e - explicitamente - contra o Estado. No caso, o brasileiro.

Voltamos, mas em outro lugar, à questão que se coloca em Festa e Guerra: que festa, então, é essa? Como pensar o modelo anfitrião-convidado aqui? E quem é o dono de festa? Quem recebe aqueles que chegam, dá comida, distribui palavras, faz grupo e, complementarmente, se confirma enquanto chefe (ou

\footnotetext{
${ }^{6}$ Entrevista concedida aos autores no dia 25/04/2017, ainda não publicada
} 
anfitrião)? Em suma, se "[t]odo dono de festa é um puxador de movimento" (PERRONE-MOISÉS, 2015, p. 43), quem vai à frente e puxa o ATL?

Podemos procurar essas respostas na logística básica, naqueles que o bancam: as organizações indígenas e indigenistas. São elas que fazem os arranjos burocráticos necessários para viabilizar todo o Acampamento. No dia a dia, eram os membros dessas associações, congregados sob a imagem e nome da Apib e da Mobilização Nacional Indígena (MNI), que recebiam os convidados, organizavam as atividades previstas e garantiam a comida, além de outros serviços básicos, como a saúde. Seriam as organizações, portanto, as anfitriãs, e as delegações dos diversos povos, os convidados? Mas, uma vez que tanto delegações quanto organizações são compostas por muitos dos mesmos sujeitos, como situar a relação anfitrião-convidado?

Recuperemos das etnografias reunidas por Perrone-Moisés os atributos de um anfitrião (e, por extensão, de um chefe): "aquele que recebe, anima, alimenta, faz viver" (2015, p. 65); "relação [...] de quem dá existência (no sentido de originar e alimentar) a sujeitos que o fazem ser quem é: xamã, pai, sogro, chefe de guerra, líder de caçada, dono de aldeia, dono de festa" (p. 68); "o indivíduo que foi capaz de mobilizar" (SILVA apud PERRONE-MOISÉS, 2015, p. 45).

Outra relação estabelecida por Perrone-Moisés, levantada a partir de análise de Stolze Lima, é a do chefe-anfitrião como "dono" do espaço em que é realizada a festa (2015, p. 76). Tal noção dificulta a simples afirmação de que as organizações financiadoras do ATL poderiam ser vistas como as anfitriãs/donas do evento, erguido sobre uma área regida pelo nosso conceito de "público". Até mesmo porque, pensemos naquilo que faz um "dono" entre os ameríndios. Como Marcio Silva observa a respeito do "dono de casa" waimiri-atroari, figura que lidera ou congrega um grupo local, esse estatuto "parece se associar menos à propriedade da casa, do que propriamente à sua construção. Um dono de casa é assim o indivíduo que foi capaz de mobilizar" (apud PERRONE-MOISÉS, 2015: 45, grifo nosso).

Isso posto, encontramos mais uma vez o problema da oposição anfitrião-convidado: se "dono" é a figura que "puxa" a construção, que começa a construir e é capaz de reunir em sua turma pessoas o bastante para garantir a construção, não nos apontaria novamente à comissão organizadora (Apib-MNI) e assim à questão de que a(s) organização(ões) é(são) feita(s) por sujeitos anfitriões e convidados?

Parece que, para driblar esse emaranhado, é necessário atentar-se ao fato de que, se o ATL é uma articulação política feita para/contra o Estado brasileiro e, nesse sentido, aos moldes dos brancos (organizações indígenas, protocolos burocráticos), não deixa de ser afetado pelos modos ameríndios de fazer política: na festa e na guerra. "A festa é congregação e produção de diferenças, celebração de alianças" (PERRONE-MOISÉS, 2015, p. 80, grifos nossos) e, no ATL, isso não se mostra diferente: é produção de diferença, intensiva e extensiva, em relação aos brancos e aos seus modos de fazer política.

O movimento indígena não é, e nunca foi, convidado a participar da festa dos brancos na política brasileira. Sempre apareceram em Brasília como invasores e indesejados (ainda que sejam eles, exatamente, os que foram e seguem sendo invadidos por nós). Ocupam a Funai, ocuparam a Constituinte, ocupam os espaços que são sistematicamente negados a eles. O ATL não escapa dessa constante. Ocupação indígena dos espaços que lhes são negados. Anfitriões e/ou convidados, organizações e/ou seus membros, são todos invasores sob o olhar daquele que se diz "dono" (na nossa concepção), isto é, o Estado. Temos, então, uma festa (e, portanto, uma política) em que todos são penetras. Uma festa que acontece na aldeia inimiga por excelência. Os que puxam a festa coordenam uma invasão, que é, ao mesmo tempo, guerra para fazerem valer direitos constitucionais invisibilizados e negados cotidianamente pelo Estado contra o qual se colocam.

Aqui, surge outro ponto em que o caso etnográfico exige um ajuste teórico. Enquanto o plano festa-guerra trabalhado por Perrone-Moisés articula-se entre momentos de festa e momentos de guerra e os chefes oscilam entre uma função-festeira e uma função-guerreira, o ATL parece imbricar esses momentos e funções. 
É festa na guerra e guerra na festa, sobrepondo ambos os polos em muitos momentos ${ }^{7}$. Mesmo se utilizando de várias das nossas armas (as "falas duras" do direito, os conhecimentos escolares e universitários), fazem da guerra com o Estado também uma festa, aderindo e, ao mesmo tempo, indigenizando a nossa forma de política.

Diante deste contexto, é possível afirmar que a categoria "política" pode ser tratada como "categoria de ida y vuelta" (CARNEIRO DA CUNHA, 2009): categoria que os povos ameríndios não imaginavam para si mesmos até que as relações com os brancos impuseram sua adoção, e que, uma vez adotada, passa por transformações próprias a seus regimes e volta aos brancos de maneira difratada. O que cabe aqui, contudo, não é esmiuçar os conceitos de Carneiro da Cunha, mas se atentar a como os indígenas lidam com esse encontro equivocado de políticas, e quais as soluções inventadas e praticadas por eles: "[m]ais do que seguir o velho modelo das festas, essas novas formas indígenas de 's’assembler' continuam sendo festas' (PERRONE-MOISÉS, 2015, p. 91).

Muitas vezes, para os ameríndios, falar de "política" (sobretudo a nossa) é falar de guerra: "Dizem, por exemplo, que 'é muita política' para se referirem a ambientes de discussão, ou que são 'bons de política' os que se destacam no movimento indígena. 'Bom de política' é sinônimo de 'bom de briga"' (PERRONE-MOISÉS, 2015, p. 87). E, como não existe festa sem guerra - uma vez que os convidados são, antes de forasteiros, potenciais inimigos (não se faz festa só entre os seus) -, e não existe guerra sem festas, a festa sempre precede e procede iniciativas de guerra. As sociedades ameríndias são, portanto, sociedades-para-a-guerra na mesma medida em que são para-a-festa: dois lados de um mesmo contra o Estado. Em Brasília, os indígenas mostram que festejar pode ser uma tática de guerra.

\section{Por que canta o ATL?}

As relações que tentamos estabelecer até aqui, entre festa-guerra, grupo e música deixam-se transparecer ainda mais num momento de intensidade. Para usar uma imagem cara aos ameríndios, é no brilho ofuscante que mais se pode (ou mais profundamente) vislumbrar o que está no(s) mundo(s). "É bem possível", escreveu Anthony Seeger, "que haja lugares e ocasiões em que a música seja a modalidade preferencial para muitos processos sociais" (2015, p. 16). A conceituação ameríndia do político parece indicar um desses "lugares". O ATL certamente é uma ocasião em que isso aparece magnificado, pela amplitude do evento, pela visibilidade que tem em relação aos brancos e ao Estado e pelas enormes diferenças que, cantadas, articulam-se. E a última grande ação da semana encorporou e mostrou tais adensamentos de maneira reluzente.

Após o ataque violento aos indígenas por parte da polícia na terça-feira (25), eles se reuniam para ocupar novamente a Esplanada dos Ministérios na tarde de quinta-feira (27). Entre falas da organização e de outras lideranças no palco, rodas formavam-se em torno da tenda principal em preparação à derradeira caminhada. Uma grande aglomeração Guarani Mbya cantava, dançava e rezava num círculo constituído ao redor das faixas que levariam na manifestação, neste momento estendidas no chão ao centro do grupo. Alguns Kaiowá também faziam rezas adiante. A delegação xinguana, à frente, exibia seus corpos ricamente enfeitados e pintados. Mais atrás, os Kaingang entoavam o que eram seus cantos de guerra (Paola Gibram, com. pess.). Saíram aos poucos da área do acampamento, delegação por delegação. Bloquearam a avenida para passar até aos gramados, pondo-se em direção ao Congresso Nacional enquanto policiais tentavam conter e enquadrar os fluxos de pessoas ao perímetro permitido.

Apesar de saber que, dois dias antes, aquelas mesmas forças haviam agido de forma bruta e violenta, era visível que algum efeito era produzido sobre elas pelas músicas daqueles corpos pintados e adornados que dança-

\footnotetext{
${ }^{7}$ Remetemos aqui a um comentário de Eliel Benites, liderança Kaiowá do Mato Grosso do Sul, a respeito de um dos cenários de guerra mais violentos do Brasil, as áreas de disputa territorial em seu Estado. Benites afirmou, contra tudo que poderíamos imaginar, que "retomada é festa" (Lauriene Seraguza, com. pess.).
} 
vam. Não era só o "exótico" que gerava estranhamento, levando os policiais a se portar de maneira sensivelmente distinta da que estamos acostumados a encontrar tantas vezes em manifestações. A estética produzida e exibida naquele momento, de fato, parecia exercer alguma agentividade. De muitas maneiras, via-se ali uma estética feita política (a deles), ou vice-versa. E ela, no mínimo, pareceu manter os policiais amansados ao longo do caminho.

Em mais um contraste com a nossa política, que faz gritar em uníssono nas manifestações, já que nossos bordões e nossa opinião comum é de que união - no sentido de ação coordenada e convergente - produz força, lá os gritos (na verdade, cantos), a todo momento e intencionalmente, diferiam. E com uma tal paisagem sonora, uma sorte de "turmas" apareceu numa multidão que já não era mais uma. Em cada canto que se colocava, o ato era um outro. Inicialmente junto de uma turma Kaiowá, atravessamos um agrupamento Xukuru e acabamos no meio de uma densa música Guajajara. Uma voz masculina entoava algumas frases num som de forte intensidade, e era entrecortado por um coro feminino que respondia. Assim o canto se repetia, retomando essa sequência sem parar. Os corpos se mexiam com vigor, às vezes pulavam e, como os maracás agitando-se no ar, não cessaram ao longo de todo o percurso. $\mathrm{O}$ ato que víamos ali, era Guajajara. Estivéssemos noutro canto, estaríamos noutro ato. Os cantos faziam aparecer turmas e refratavam nossa percepção do que estava ao redor. $\mathrm{O}$ ato que se enxergava dependia, de alguma forma, de qual dos atos se escutava.

Ao fim dos Ministérios, todos pararam no gramado diante do Congresso, onde havia um cordão de isolamento que impedia de prosseguir. Os bandos musicais que chegavam, cada um a seu timbre e compasso, quedavam-se num ou noutro ponto. Alguns dos que cantavam daqui se juntaram a outra turma, e movimentos do tipo aumentaram. Algumas sonoridades se transformaram e a composição de certas turmas se reconfigurou. Num momento, uma mesma aglomeração contava com um Xavante, alguns alto-xinguanos, outros Kaingang e uma turma de Guajajara. Essas (re)composições de grupos e de cantos assim seguiram por um tempo, até que, como num crescendo corporificado, tomou forma uma grande roda que circulava extensa área do gramado e congregava quase todos que lá estavam. Manteve-se num movimento lento, como um gigantesco corpo, pouco ágil, e, subitamente, explodiu em milhares de pontos, em gritos e correrias desordenadas rumo à extremidade oposta do Eixo Monumental. Espalhados e sem qualquer organização aparente, correndo aos gritos, recompuseram-se numa enorme aglomeração entoando o que agora formava novamente o som inteligível de “Demarcação já!". Os policiais observavam, e seguiam amansados.

Como observa Perrone-Moisés, “[a]s festas, antigas ou novas, fazem grupos” (2015, p. 50). Aqui, parecem fazê-los sobremaneira pela música, pelos cantos de festa e de guerra. Os grupos - talvez melhor chamá-los de instanciações de coletividades - aparecem a partir das diferenças de cantos. Não parece, como suporia uma interpretação culturalista, que tais cantos sejam uma marca étnica de um determinado grupo, expressão quase contingente de uma substância. Nós que somos "Guarani" ou "Pataxó" cantamos juntos por pertencermos a essa mesma região de etnicidade, por assim dizer. Parece, antes, que "ser" Guarani ou Pataxó, nesses momentos, é efeito de produzirem música em comum, que ao mesmo tempo os congrega entre si e os diferencia dos que cantam outros cantos - enquanto cantarem diferentemente. De forma que isso que chamamos "grupo" vem a existir a partir de afastamentos diferenciais dados pelas distintas "receitas e ingredientes" musicais.

O que significa dizer também que essas instanciações de coletividades não se traduzem em "grupos corporados". Se as diferenças são postas e repostas pela música, ao unir as vozes num canto comum, podem também - e enquanto este canto durar - participar e se entender enquanto uma mesma coletividade em festa. Podem ainda, quando esse canto novamente se transformar e repuser as diferenças anteriores (ou produzir novas), tornarem-se inimigos, ou aliados potenciais, ou o tão disseminado "parente", termo que congrega vastas distâncias possíveis de alteridade, tamanha sua elasticidade pronominal, se assim se pode dizer. Aliança-inimizade, "os da minha turma" e "os de outra". O dualismo em perpétuo desequilíbrio materializa-se em sons. Ou melhor, a partir do sensível sonoro, coloca-se em movimento, relacionando "na 
diferença e, por ela, em eterno desequilíbrio" (PERRONE-MOISÉS, 2015, p. 60). Não cessa de congregar e transformar ao diferir e, assim, segue fazendo política - mas uma outra, contra o Estado, contra o estável, que só persiste na medida em que desequilibra as ordens existentes.

Nas terras baixas da América do Sul, observou Seeger, "sempre que se ouve música, ao que parece, algo de importante está acontecendo" (2015, p. 34). No Acampamento Terra Livre, realmente nada importante parece acontecer sem música. Uma festa silenciosa não pode ser uma boa festa e, portanto, uma política bem feita deve ser cantada. Entre os Kĩsêdjê, o autor se coloca uma questão central, pertinente a nós aqui: "por que, afinal, fazer música em dada situação, em uma sociedade?". No caso do ATL, mais do que "uma sociedade", ela aparece como matriz relacional que articula, coordena e desordena uma miríade de grupos distintos, incapazes muitas vezes de se compreenderem pela língua, mas que o fazem, em algum nível, através de cantos. Uma semântica musical que se esboça e que opera. Recuperando a questão posta por Seeger, podemos indagar por que, nessa dada situação, grupos tão variados fazem, exatamente, música? Por que o português não basta como língua franca? Não pretendemos resposta, mas os comentários etnográficos esboçados aqui, cremos, apontam trilhas teóricas possíveis para pensar o que escutamos.

\section{Referências}

CARNEIRO DA CUNHA, Manuela. Cultura com aspas e outros ensaios. São Paulo: Cosac Naify, 2009.

CLASTRES, Pierre. A sociedade contra o Estado. São Paulo: Cosac Naify, 2003.

. Arqueologia da violência - pesquisas de antropologia política. São Paulo: Cosac Naify, 2004.

GOLDMAN, Marcio e LIMA, Tânia Stolze. Prefácio. In: CLASTRES, Pierre. A sociedade contra o Estado. São Paulo: Cosac Naify, 2003.

GRAHAM, Laura. How Should an Indian Speak? Amazonian Indians and the Symbolic Politics of Language in the Global Public Sphere. In: WARREN, Kay; JACKSON, Jean (Org.). Indigenous Movements, Self Representation, and the State in Latin America. Austin: University of Austin Press, 2002.

PERRONE-MOISÉS, Beatriz. Bons chefes, maus chefes, chefões: elementos de filosofia política ameríndia. In: Revista de Antropologia. São Paulo, v. 54, n. 2, pp. 857-883, 2011. Disponível em: http://www.revistas.usp. $\mathrm{br} / \mathrm{ra} /$ article/view/39649/43145. Acesso em 28 out 2020.

Festa e guerra. Tese de livre-docência. Universidade de São Paulo: São Paulo, 2015.

RICARDO, Carlos Alberto. Quem fala em nome dos índios?. In: RICARDO, Carlos Alberto (Org.). Povos indígenas no Brasil 1991-1995. São Paulo: Instituto Socioambiental, 1996.

SEEGER, Anthony. Por que cantam os Kĩsêdjê - uma antropologia musical de um povo amazônico. São Paulo: Cosac Naify, 2015.

Recebido em 31/10/2020

Aceito em 23/11/2020 
